\title{
A ARTE PÚBLICA ENTRE PATRIMÓNIO E IDEÁRIO. O ITINerário artístico de Siah Armajani
}

\author{
José Guilherme Abreu
}

Centro de Investigação em Ciência e Tecnologia das Artes, Escola das Artes, Universidade Católica Portuguesa, Portugal

\begin{abstract}
RESUMO
Siah Armajani (1939-) é um escultor de origem iraniana que ainda muito jovem emigrou para os EUA, onde empreendeu uma carreira artística, sediada em Minneapolis, no Minnesota. Para além de autor de uma vasta e reconhecida obra escultórica, Armajani é também um ensaísta, sendo autor do texto "Manifesto public sculpture in the context of american democracy" (Armajani, 1995), que acompanhou a exposição "Espaços de Leitura" que apresentou, em 1995, no Museu d'Art Contemporani de Barcelona (MACBA). O interesse da obra de Armajani decorre da mesma resultar de um inequívoco engagement a um ideário sócio-utópico-artístico que problematiza o estatuto do regime autoral, e que rejeita a autorreferencialidade da obra, circunstância rara no contexto da produção artística contemporânea. Esteticamente contemporânea, a obra de Armajani logra resolver um dos dilemas mais amargos da arte moderna e contemporânea, formulado por Arnold Schoenberg: "se é arte, não é para todos, e se é para todos não é arte" (Schoenberg, 1950, p. 124). Curiosamente, o ideário veiculado por Armajani não é em absoluto inédito. Em múltiplos aspetos o mesmo coincide com o do movimento em prol da arte pública que se formou na Bélgica, nos finais do século XIX, e que deu origem à organização de quatro congressos internacionais de arte pública, dois deles com participação portuguesa documentada, aspeto por onde se inicia o presente estudo.
\end{abstract}

\section{Palavras-Chave}

arte pública; Instituto Internacional de Arte Pública; património; Siah Armajani; manifesto

\section{Public ART BeTWeen heritage AND ideario. The arTistic ITINeRARy of Siah Armajani}

\begin{abstract}
Siah Armajani (1939-) is an Iranian born sculptor who quite young emigrated to USA, where he began an artistic career in Minneapolis, Minnesota. Beyond being the author of a vast and acknowledged sculptural work, Siah Armajani is also an essayist, having authored "Manifesto public sculpture in the context of american democracy" (Armajani, 1995), which was written for the exhibition "Reading Spaces" he presented, in 1995, at Museu d'Art Contemporani de Barcelona (MACBA). The value of Armajani's work comes from its engagement to an unequivocal social-utopic-artistic ideario that problematizes the prevalence of the authorship's statute regime, while rejecting the self-referential character of the artistic work, being both aspects quite unusual in the field of contemporary art production. Aesthetically contemporary, Armajani's work succeeds to solve one of the bitter dilemmas of modern and contemporary art, as Arnold Schoenberg brightly put into words: "if it is art, it is not for all, and if it is for all, it is not art" (Schoenberg, 1950, p. 124). Curiously, Armajani's public sculpture ideario is not absolutely unique. In several points, it matches the one of the movement in favour of public art, which by the end of the $19^{\text {th }}$ century had been formed in Belgic, giving birth to the organization of four public art international
\end{abstract}


congresses, two of them having documented Portuguese participation, as we will see in the first section of this paper.

\section{KEYWORDS}

public art; International Institute for Public Art; heritage; Siah Armajani; manifesto

\section{UM RETORNO ÀS ORIGENS?}

A escultura pública pretende preencher o fosso que se forma entre a arte e o público, para fazer com que a arte seja pública, e com que os artistas sejam de novo cidadãos.

(Siah Armajani, 1995, p. 36)

A origem da arte pública, assim designada, remonta ao último quartel do século XIX, tendo surgido na Europa sob a influência do movimento Arts and Crafts, a cujo ideário a mesma foi beber os enunciados estéticos e os programas artísticos que depois adotará.

Logo a seguir, um movimento similar irrompe nos Estados Unidos, influenciado, por sua vez, pelo movimento City Beautiful, cujos traços monumentais e ecléticos adotará, diferenciando-se do movimento europeu, fundado como já foi referido nos pressupostos ornamentais e socializantes do citado movimento britânico.

Apesar de distintos, em ambos os movimentos descobre-se uma curiosa afinidade maçónica, que se manifesta na filiação de alguns dos seus principais mentores como Charles Buls (1837-1914), filiado na loja maçónica Les Vrais Amis, de Bruxelas, desde 1862, e presidente, a partir de 1894, da Société l'Euvre Apliquée à la Rue et aux Objets d'Utilité Publique, que virá a ser o embrião do movimento belga a favor da arte pública (Abreu, 2010, p. 24). Além de Buls, também o arquiteto Victor Horta, notável criador da Art Nouveau bruxelense, e apoiante dos congressos internacionais de arte pública, foi destacado franco-maçom, filiado na loja Les Amis Philantropes (Resseler, 2013, p. 93).

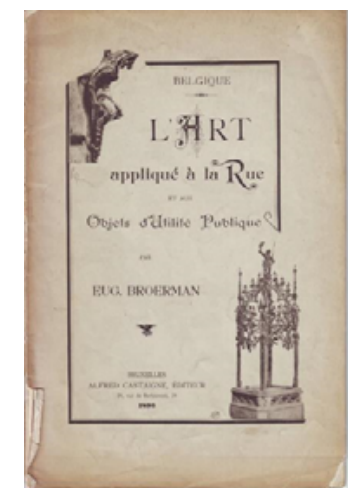

Figura 1: L'Art Appliqué à la Rue et aux Objets d'Utilité Publique

Fonte: Broerman, 1895 (fotografia de José Guilherme Abreu) 


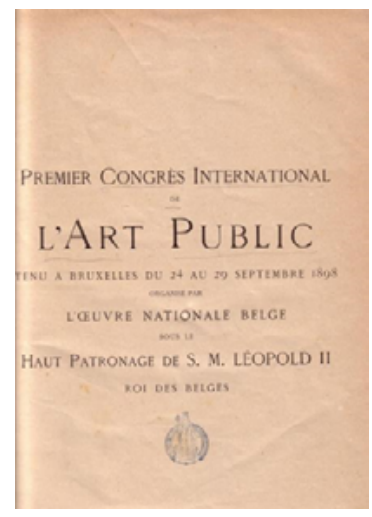

Figura 2: Premier Congrès International d'Art Public Fonte: Broerman et. al., 1898 (fotografia José Guilherme Abreu)

O mesmo sucede, curiosamente, com o movimento norte-americano, onde pontuam nomes como Daniel Burham (1846-1912) que foi autor do Templo Maçónico de Chicago (1892), diretor da "Exposição Universal Columbiana de Chicago" (1893), bem como do Plano Urbanístico de Chicago (1909), e que "foi um dos mais visionários maçons, arquitetonicamente falando" (Johnstone, 2018, p. 179). A par de Burnham, também Richard Watson Gilder (1844-1909) foi franco-maçom, tendo sido o fundador, em 1899, da Public Art League of the United States de que foi presidente, tendo a mesma como vice-presidente Augustus Saint-Gaudens e Glenn Brown como secretário-geral (Mechlin, 1922, p. 185).

Centrado na Bélgica, o movimento europeu culminou na organização de quatro congressos internacionais de arte pública, entre os anos de 1898 e 1910 . Esses congressos reuniram um grande número de representações oficiais, as quais compreenderam destacadas figuras dos governos de países da Europa, da América do Norte e do Sul e até da Ásia, tal como representantes de municípios e de comunidades urbanas, onde avultavam dezenas de câmaras municipais, entre as quais as de Lisboa e de Coimbra, assim como uma representação oficial do município de Madrid.

Três destes congressos produziram detalhados catálogos (Broerman et al., 1898; Broerman et al., 1905; Broerman et al., 1910), importando salientar que uma das resoluções do III Congresso, em 1905, foi fundar um órgão internacional permanente em prol da arte pública, órgão esse que teve a designação de Institut Internacional d'Art Public, (IIAP) o qual, a partir de 1907, teve como porta-voz a revista L'Art Public, que editou, até 1910, um total de oito números trimestrais, alguns deles duplos.

É importante para os propósitos do presente estudo analisar os estatutos do Institut Internacional d'Art Public, publicados no n. ${ }^{\circ} 1$ da revista L'Art Public, assim como fazer um levantamento das temáticas tratadas no número inaugural da revista.

Pelo levantamento realizado (ver Tabela 1, nos Apêndices), é possível perceber os fundamentos, os propósitos e o alcance do IIAP. É impressionante o grau de envolvimento e de desenvolvimento institucional e político enunciado pelos estatutos do IIAP. 
E ainda mais impressivo o mesmo se torna, se considerarmos o facto de que nos anos que precederam a Grande Guerra, o conceito de arte pública era muito mais alargado do que presentemente, tal como observa Marcel Smets:

o que impressiona é sobretudo a extrema diversidade dos assuntos que aí são abordados. A arte pública aplica-se tanto à educação como ao teatro, à legislação, ao restauro, às qualidades e à profissão do artista, a conservação dos sítios, o desenho urbano e o aspeto do domínio público. Ao longo dos doze anos que separam o primeiro e o último congresso, nenhum destes domínios de impuseram, mesmo se o número de comunicações relacionadas com o ordenamento urbano tenha crescido gradualmente. (Smets, 1995, p. 146)

Ou seja, mau grado a diversidade de linguagens e de formas de intervenção artística que hoje se manifestam no terreno multidisciplinar que é presentemente a arte pública, deve no entanto reconhecer-se que as modalidades de intervenção contemporânea se concentram quase exclusivamente no território alargado das artes plásticas, ao contrário do que sucedia com o referido movimento belga. Aí, o universo de incidência abrangia uma panóplia de áreas bastante numerosas e diferenciadas, como passamos a enumerar:

- educação;

- teatro;

- legislação;

- restauro;

- música popular;

- mobiliário urbano;

- profissão artística;

- conservação de sítios;

- traçado urbano;

- aspeto do domínio público.

Pelas áreas listadas, percebemos que o movimento a favor da arte pública se concebia não apenas como uma dinâmica de produção artística, mas também como um movimento de salvaguarda e valorização do património.

De resto, se existia uma tendência dominante no referido movimento, essa tendência era a de preservação das riquezas artísticas do passado, concebendo-se o movimento em prol da arte pública, do ponto de vista programático, como um movimento de defesa do património cultural e artístico, muito embora alargando-o bem para lá do culto dos monumentos históricos, por a par destes integrar toda uma panóplia de bens culturais e artísticos, reunindo, curiosamente, numa mesma família, bens materiais e bens imateriais, antecipando-se assim ao conceito de património imaterial, o que não deixa de ser precoce, senão mesmo prodigioso. 
Por um lado, progressista, dado o caráter alargado do conceito de arte pública que professava, por outro, assaz retórico, o movimento não logrou estabelecer um afastamento crítico face aos fundamentos, propósitos e realizações do historicismo. Ao contrário, o movimento a favor da arte pública de finais do século XIX foi abertamente refratário em relação às teses e às práticas de rutura da modernidade nas artes plásticas, aspeto que contribuiu para a erosão da sua orientação estética, não sendo por acaso que o movimento soçobrou a partir do IV Congresso, realizado em Bruxelas, em 1910, cujo catálogo é uma sombra, se comparado com o do III Congresso de 1905, cuja extensão é de 744 páginas, enquanto o do IV Congresso não foi além das 176 páginas.

A tensão entre progressismo e conservadorismo é notória nos conteúdos das edições da revista do IIAP. No número inaugural, editado em junho de 1907, no índice figuravam os seguintes assuntos:

1. A arte pública, por Eugène Broeman

2. Tradições nacionais

2.1. Mistral et le Félibrige. Poema provençal, por Marius Mistral

2.2. A cidade de Paris e a arte pública no século XVI, por Marius Vachon

2.3. Pela beleza, por Carmen Sylva

2.4. A educação artística nacional, por Walter Crane

3. Salvaguarda dos sítios e dos patrimónios artísticos

3.1. A ressurreição de Herculanum, $H$. Carlon de Wiart

3.2. As ardenas e a gruta de Hans, Ed. De Pierpont

4. Evolução artística das cidades

4.1. As transformações de Bruxelas, L. Dumont-Wilden

4.2. Da construção moderna das cidades na Alemanha, por J. Siebben

4.3. O desenvolvimento artístico das cidades americanas, por Glenn Brown

4.4. O papel da crítica de arte, por Frantz Jourdain

5. A cultura estética

5.1. Imagem na escola, por A. Stuys

5.2. Ensino da arte industrial na Holanda, por von Saher

5.3. O canto popular, por Ft. Van Dayse

5.4. Curso de estética, por Mario Pilo

5.5. Carta do síndico de Florença, por J. Niccolini 


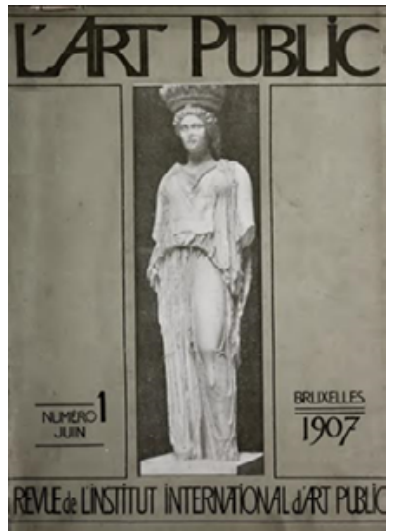

Figura 3: L'Art Public, n. ${ }^{\circ}$ 1, $1 / 6 / 1907$

Fonte: Broerman, 1907 (fotografia José Guilherme Abreu)

O índice da revista reitera o assumir da noção alargada de arte pública. Pelas quatro secções em que se repartem os vários artigos, e ainda mais pelas suas incidências, torna-se inequívoca a abrangência do espectro de inclusão do conceito de arte pública.

Pareceu-nos útil reproduzir aqui esta amostra, para de forma objetiva e rigorosa proceder à análise dos testemunhos documentais do movimento a favor da arte pública criado pelo IIAP, pois apesar da dimensão institucional que este chegou a deter, após a Grande Guerra, o mesmo caiu no esquecimento e, inclusive no campo do estudo especializado da arte pública, não é assunto que se possa considerar bem conhecido.

Pelo material coligido, (ver Apêndices, Tabela 1) podemos retirar pertinentes ilações para aquele que constitui o escopo do presente estudo. Passamos a enumerá-las:

1. na sua fase inicial, o movimento em favor da arte pública foi antes de mais uma tomada de consciência do valor do património cultural e artístico, entendido para lá dos limites da salvaguarda dos monumentos históricos, desencadeada pelas vandalizações levadas a cabo pela fúria demolidora dos sans-culottes, em Paris, durante a Convenção;

2. da mesma forma, o referido movimento desenvolvido pelo IIAP pugna pela valorização estética das cidades, reivindicando para tanto o concurso da arte, resgatando-a do domínio privado das coleções particulares e/ou institucionais, visando a sua função e fruição a partir de preocupações e objetivos eminentemente pedagógicos;

3. firme zelador do legado patrimonial, o IIAP interessa-se ainda pela investigação e valorização do património arqueológico, promovendo a organização de escavações arqueológicas criteriosas a fim de trazer a público os testemunhos do passado;

4. não se restringindo à proteção e promoção do património artístico objetual ou monumental, o IIAP denota ter consciência do valor patrimonial do território, promovendo a preservação e valorização dos espaços naturais e da paisagem, antecipando a noção de paisagem cultural;

5. para lá da valorização dos contextos paisagísticos e das riquezas naturais, o IIAP interessa-se e zela pela valorização da tradição oral e dos usos e costumes das comunidades, pugnando pela salvaguarda da canção popular e etnográfica (o cante) bem como do teatro e das festas populares, antecipando-se assim à noção contemporânea de património imaterial;

6. finalmente, o IIAP defende um entendimento, por assim dizer, utilitário da arte, reservando-lhe uma função social de primeira grandeza, no quadro da formação do ser humano e da promoção do progresso, na senda do positivismo, onde se pode reconhecer a sua conotação maçónica. 
Eis assim enunciados alguns dos traços que definem, já na sua origem, aquilo que costumo designar como sendo o "ideário da arte pública" (Abreu, 2015).

A metodologia que usamos pode ser replicada nos restantes números da revista L'Art Public, embora não caiba fazê-lo aqui. De resto, a estrutura de assuntos presente nos índices dos oito números publicados mantém-se (ver Apêndices, Tabela 2).

Da mesma forma, se fizermos uma incursão pontual nos votos (recomendações) do "IV Congresso Internacional de Arte Pública", realizado em Bruxelas, em 1910, verificamos a persistência da mesma estrutura de incidências e de atuação, estrutura essa a que adicionamos o cômputo de recomendações por cada secção, como discriminamos:

- I I secção: salvaguarda dos sítios e patrimónios de arte (20 recomendações);

- II secção: extensão artística das cidades (13 recomendações);

- III secção: cultura estética (15 recomendações);

- IV secção: educação artística do povo (8 recomendações).

Destes dados pode inferir-se a consistência metodológica e a coerência conceptual do quadro epistemológico e operativo do IIAP.

Não é conhecido o historial que rodeou a extinção do IIAP, nem esse aspeto é relevante para o presente estudo. $O$ que nos parece fundamental é perceber se o ideário que detetámos como estando na origem do movimento desenvolvido pelo IIAP constitui, de facto, um elemento estrutural de uma definição informada de arte pública, e se esse mesmo ideário se mantém atual, no sentido de apurar se se podem descobrir elementos comuns entre os traços desse mesmo ideário, tal como o identificamos mais acima, e a teoria e a prática da arte pública contemporânea, como discutiremos de seguida.

\section{O IDEÁRIO DA ARTE PÚBLICA, NO ÂMBITO DO SEU COMPLEXO CONCETUAL}

Em estudo elaborado num outro lugar, defendemos que a arte pública contemporânea é um território de tendências (Abreu, 2018), facto que dificulta enormemente a elaboração de uma definição que seja válida e aplicável aos diversos segmentos que hoje a constituem, embora a sua variedade seja menor hoje que no período da sua formação.

Num outro estudo (Abreu, 2015), em vez de propormos um conceito de arte pública, propusemos antes um complexo conceptual, o qual se estrutura a diversos níveis, um dos quais é precisamente o nível do ideário.

Esse complexo conceptual estrutura-se a partir de quatro pilares:

1. ideário: a arte pública visa fazer chegar a arte a todos os cidadãos para ajudar a melhorar a sua vida coletiva e a sua evolução cultural;

2. impacto: a arte pública implica uma postura cívica do artista e provoca um comportamento social do público (apropriação ou rejeição);

3. inclusividade: a arte pública adequa-se a múltiplos destinatários, técnicas de produção, meios expressivos, linguagens plásticas e formas de expressão. Em coabitação pluridimensional;

4. regime: a arte pública resulta de um regime de produção alogerada (Abreu, 2013, p. 20) distinto da restante produção artística. (Abreu, 2015, p. 45) 
Pelo exposto, verificamos que o ideário é o primeiro pilar, senão o fundamental, do complexo conceptual.

Defendemos também que existe uma genealogia que liga e articula, em sucessivas adaptações e formulações, enunciados distintos desse complexo conceptual, desde a sua génese em finais do século XIX, inspirado no ideário do movimento britânico Arts and Crafts (Abreu, 2013, p. 18), até à atualidade, transpondo assim o fosso da cronologia e as vicissitudes da conturbada História do séc. XX.

Ao falarmos em genealogia, não pretendemos dizer que a linhagem que lhe dá corpo, forme uma sucessão cronológica contínua, sem hiatos e sem mudanças de direção.

É esse concretamente o caso de Siah Armajani. Embora não se possa dizer que a sua linha de produção seja marginal no âmbito dos circuitos internacionais da arte contemporânea (culturais, institucionais e mercantis), importa reconhecer que a mesma não repercute os pressupostos estéticos e/ou conceptuais preponderantes entre os artistas contemporâneos. É que, Armajani optou por dar continuidade a uma linha de produção que havia sido "descontinuada", depois de terminado o ciclo das vanguardas históricas.

Essa corrente artística é o construtivismo e a sua repercussão na obra de Armajani pode comprovar-se confrontando a produção do artista com a explicitação dos preceitos do construtivismo, em 1921, pelo próprio Rodchenko:

a construção é a disposição de elementos.

A construção é a filosofia moderna.

A arte como qualquer ciência é um dos ramos da matemática.

A construção representa a exigência contemporânea de organização e o uso utilitário de materiais.

A vida construtiva é a arte do futuro.

A Arte que não participa na vida deve ser conservada em museus arqueoló-

gicos da Antiguidade.

É chegado o tempo de a Arte fluir organizadamente na vida.

Uma vida organizada construtivamente supera a arte mística dos mágicos.

(...)

Consciência, experiência ... função, construção, tecnologia, matemáti-

ca - estes são os irmãos da arte do nosso tempo. (Elliott, 1979, p. 129)

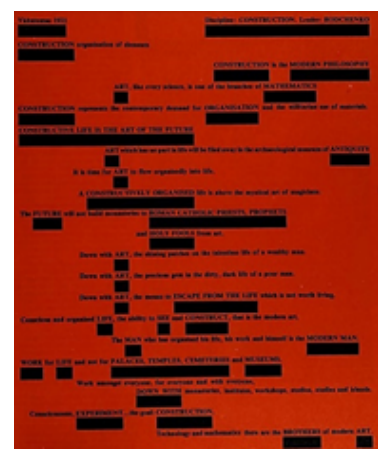

Figura 4: Rodchenko (1921), Notas para uma aula

Fonte: Elliot, 1979, p. 29 
Como veremos mais adiante, mau grado a distância cronológica e o fosso cultural entre ambos os artistas, estas premissas integram a produção material e teórica de Armajani, como o próprio artista, de resto, o reconhece:

eu estava interessado nos construtivistas porque eles eram políticos, porque neles não havia separação entre o cidadão e o artista - algo que estamos agora a tentar fazer na arte pública. Eles são realmente o nosso paradigma, Tatlin e Rodchenko e Malevich e os outros. (Tomkins, 1990, p. 54)

Rejeitado pela normativa jadnoviana do estalinismo, o construtivismo foi posteriormente absorvido pela Bauhaus, para onde, de resto, transitaram artistas da vanguarda soviética, ou próximos da mesma, como Wassily Kandinsky, Nikolaus Pesvner e o seu irmão Naum Gabo, onde viriam a ser proeminentes professores. Na Bauhaus, porém, o construtivismo evoluiu sobretudo no sentido do design, perdendo a sua dimensão cívica, como se observa na linha de produção de Gabo e Pevsner.

Genealogia não-linear, desde logo porque a linguagem plástica de Armajani inverteu, por sua vez, a inversão antes introduzida pela Bauhaus, evoluindo agora de design de interior para equipamento de exterior, centrando-se, embora não unicamente, na construção de estruturas e de espaços de lazer, destinados ao espaço público citadino, a jardins urbanos, a locais de estudo, a recintos desportivos ou a recônditas áreas naturais.

As pontes pedonais foram o primeiro tipo de estruturas construtivas desenhadas por Armajani. A primeira ponte que construiu data de 1968, e foi instalada temporariamente num terreno do parque de Bear Lake City, no Minnesota.

Dessa instalação apenas subsiste a maqueta. Seria a primeira de uma longa série cujos primeiros exercícios exprimem a ideia de desfuncionalização' e de questionamento (Figura 5) da sua utilidade prática imediata.

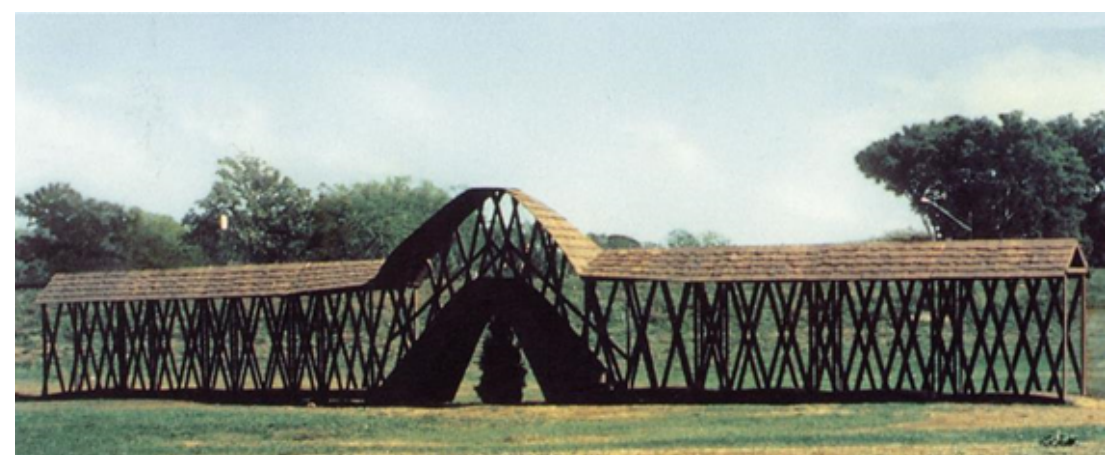

Figura 5: Siah Armajani (1970), Bridge over a Nice Triangle Tree, obra temporária em Minneapolis Sculpture Garden, Estados Unidos

Fonte: "Return to exile Siah Armajani" (2010, s. p.)

Mas a influência da arquitetura e da construção em geral não são as únicas premissas do trabalho artístico de Armajani. Além dessa matriz, uma outra radicalmente

\footnotetext{
' Ver https://www.artsy.net/artwork/siah-armajani-first-bridge
} 
distinta, senão oposta, moldou o seu pensamento artístico: a arte conceptual, sendo pelo cruzamento de ambas as correntes que se define a sua obra.

Em 1969, entre a instalação em Bear Lake City e a instalação no Minneapolis Sculpture Garden, Armajani participou na célebre exposição de arte conceptual "Information", que decorreu no MoMA, entre 20 de julho e 3 de setembro de 1970.

Nessa exposição, Armajani apresentou North Dakota Project: um desenho, e respetivos "cálculos", sobre a altura que deveria ter uma torre cuja sombra projetada se estendesse por todo o território daquele Estado norte-americano, como se refere nos registos dessa exposição existentes no MoMA:

Em Information, Armajani também está representado pelo "North Dakota Project", fotografias e cópias fotostáticas documentando a sua proposta para uma torre a ser construída na fronteira leste do estado de "North Dakota" que terá a altura suficiente para projetar uma sombra ao longo de toda a extensão do Estado até à sua fronteira oeste. (Shaw, 1970, p. 1)

Sobre o referido projeto existe a imagem e os cálculos exibidos na exposição.

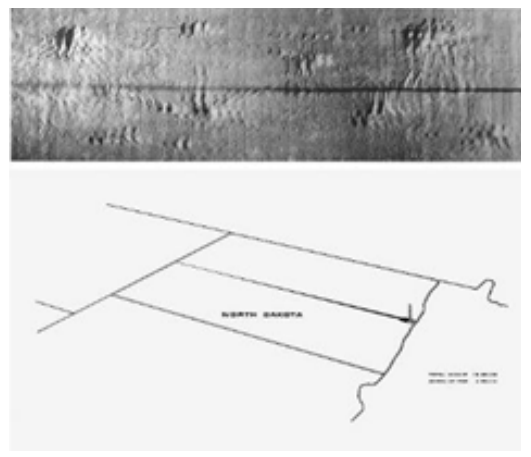

Figura 6: Siah Armajani (1970), North Dakota Tower, "Information", MoMA, 20/07/1970 - 03/09/1970, Nova lorque

Fonte: https://walkerart.org/calendar/2018/siah-armajani-follow-this-line

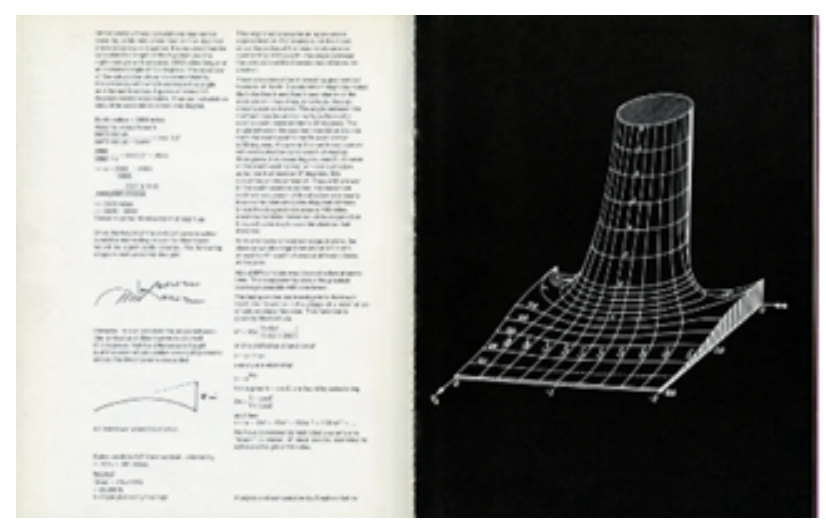

Figura 7: Siah Armajani (1970), North Dakota Tower, "Information", MoMA, 20/07/1970-03/09/1970, Nova lorque

Fonte: https://walkerart.org/magazine/on-designing-siah-armajani-follow-this-line 
Nas duas imagens à esquerda, pode ver-se, em baixo, o projeto da torre e em cima a sombra projetada sobre uma maqueta da orografia do território do Estado. Nas imagens à direita, são apresentados os cálculos da altura da torre e da sua inclinação, assim como um pormenor da sua colossal base de sustentação.

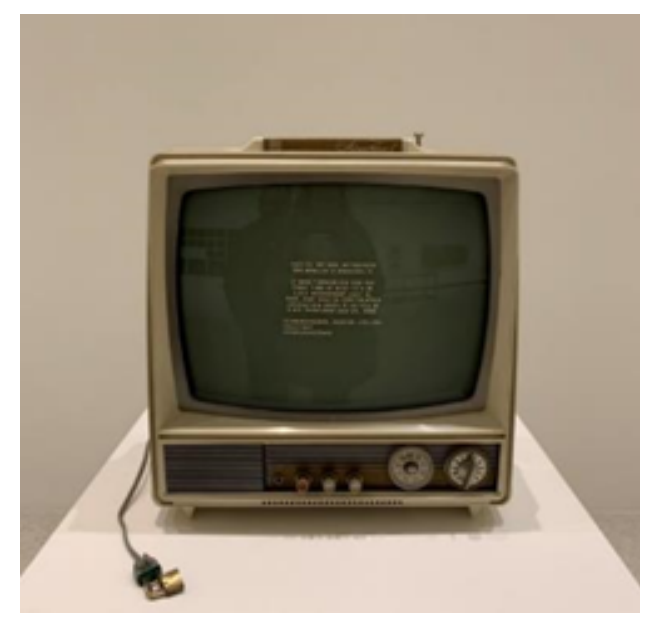

Figura 8: Siah Armajani (1969), Moon Landing, "Follow this Line", 09/09/2018 - 30/12/2018, Walker Art Center, Minnesota

Fonte: https://twitter.com/MarinRSullivan/status/1076572666402885635/photo/1

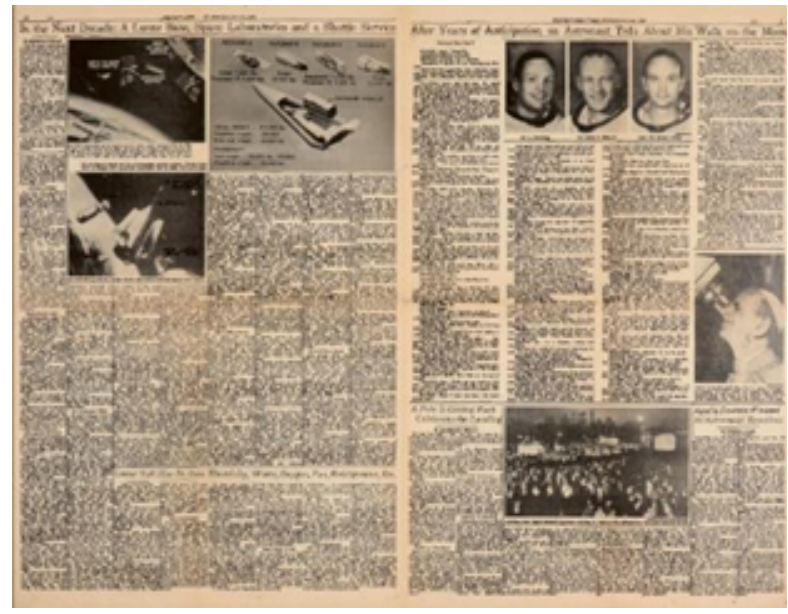

Figura 9: Siah Armajani (1969), Moon Landing, "Follow this Line", 09/09/2018 - 30/12/2018, Walker Art Center, Minnesota

Fonte: https://walkerart.org/magazine/on-designing-siah-armajani-follow-this-line

Já no ano anterior a este projeto, Armajani tinha concebido a instalação Moon Landing que reunia um televisor que o artista havia adquirido aquando do lançamento da missão Apollo 11, acompanhado da respetiva notícia da alunagem, no New York Times, cujos caracteres de imprensa haviam sido decalcados, manualmente, a esferográfica negra, pelo artista. Sobre o monitor, Armajani imprimiu a stencil, em caracteres brancos: 
Este aparelho T.V. acompanhou / A Missão Apollo 11. (1)

Esteve ligado pela / primeira vez às 8:32 (2) A.M. / C.D.T., de quarta-feira

16 de julho de 1969, e esteve em operação contínua até às 11:30 (3) A.M. /

C.D.T. de qianta-feira 24 de julho de 1969.

1. Armstrong, Aldrin, Collins

2. Liftoff

3. Spashdown

Para perceber a obra de Armajani, é necessário, pois, considerá-la na sua dupla origem ${ }^{2}$. Por um lado, a sua matriz construtivista, adaptada a uma produção artística que "deve ser aberta, disponível, útil e comum" (Armajani, 1995, p. 5). Por outro lado, a sua vertente conceptual, enraizada num ideário político, como explica "o meu interesse pela política foi induzido pela minha avó Soghora. (...) As suas histórias de diariamente correr o risco de perder a vida foram extremamente influenciadores para mim" (Armajani, 2011, p. 380).

No ponto seguinte, analisaremos como as obras públicas de Siah Armajani constroem um património em que modernidade, tradição e ideário se conjugam de forma exemplar, e no qual a arte pública se constitui como germe de um património a transmitir para o futuro.

\section{O itinerário artístico de Siah Armajani}

Siah Armajani (1937-) reúne uma vasta e disseminada produção de obras públicas, a par de uma não menos importante produção teórica que, invariavelmente, repercutem um inequívoco e assumido ideário, como se documenta na seguinte passagem:

a arte pública não se ocupa do eu, mas dos outros. Não trata de gostos pessoais, mas das necessidades dos outros. Não trata da angústia do artista, mas da felicidade e do bem-estar dos outros. Não trata do mito do artista, mas do seu sentido cívico. Não pretende fazer com que os indivíduos se sintam diminuídos e insignificantes, mas glorificá-los. Não trata do vazio existente entre a cultura e o público, mas pretende que a arte seja pública e que o artista seja de novo um cidadão. (Museo Nacional Centro de Arte Reina Sofía, 2000, p. 2)

Retirada do folheto editado pelo Museo Nacional Centro de Arte Reina Sofia, que acompanhou a exposição "Fallujah" realizada entre 30 de setembro de 1999 e 10 de janeiro de 2000, no Palacio de Cristal de Madrid, esta citação permite traçar as coordenadas do pensamento estético de Siah Armajani, pensamento estético cujo enunciado exaustivo e sistemático se encontra condensado no "Manifesto public sculpture in the context of american democracy" (Armajani, 1995), que estudaremos mais adiante.

De imediato, comecemos por analisar a produção artística de Armajani.

\footnotetext{
${ }^{2}$ A síntese da sua dupla origem aparece formulada, no documento disponível em https://www.metmuseum.org/ exhibitions/listings/2019/siah-armajani-follow-this-line/illustrated-chronology
} 
Um exemplo muito recente é o caso de Ponte sobre Árvore, cuja primeira instalação ocorreu no Minneapolis Sculpture Garden, em 1970, como já vimos (Figura 5), e que agora foi reconstruído para acompanhar a exposição "Follow this Line", em exibição no Met Breuer, Nova lorque, entre 20 de fevereiro e 20 de junho de $2019^{3}$.

Instalada de novo, entre 20 de fevereiro e 29 de setembro de 2019 , junto à Ponte de Brooklyn, Nova lorque, trata-se de uma obra necessariamente temporária, devido ao crescimento da árvore, aspeto que constitui um dos seus pressupostos conceptuais mais intrigantes, na medida em que sendo uma obra que visa uma utilização prática, na verdade o seu uso continuado é inviabilizado no tempo, em virtude da presença do cedro, que aqui assinala o caráter impermanente e transitório da própria vida.

A função desta ponte não é, portanto, a de servir uma utilidade prática, mas a de instaurar um meio de relação e de interação, ou como diz o artista, uma relação de vizinhança, entre os utilizadores que a atravessam, mesmo quando não se justifica fazê-lo, já que com maior facilidade e conforto se pode vencer a distância entre os seus extremos, evitando-a.

Esta obra de Siah Armajani torna-se assim um instrumento para a interação entre os cidadãos que a atravessam e instaura um motivo de reflexão para cada um.

Conceber-se como instrumento para a utilização e a reflexão dos cidadãos, constitui um dos pressupostos fundamentais da obra de Siah Armajani, como se pode testemunhar por outra obra marcante do artista: a Mesa de Picnic para Huesca, Aragão, Espanha.

Inserida no projeto de arte pública "Arte Y Naturaleza", da iniciativa da Diputación Provincial de Huesca (DPH), Siah Armajani foi convidado a participar no certame, e segundo o testemunho oral no congresso (Luesma, 2010) a então diretora do Centro de Documentación Arte y Naturaleza (CDAN), referiu que a forma como o artista concebeu a sua intervenção foi bastante distinta da dos restantes artistas. Em vez de propor uma peça, começou por perguntar de que é que sentiam falta, no espaço natural de Huesca.

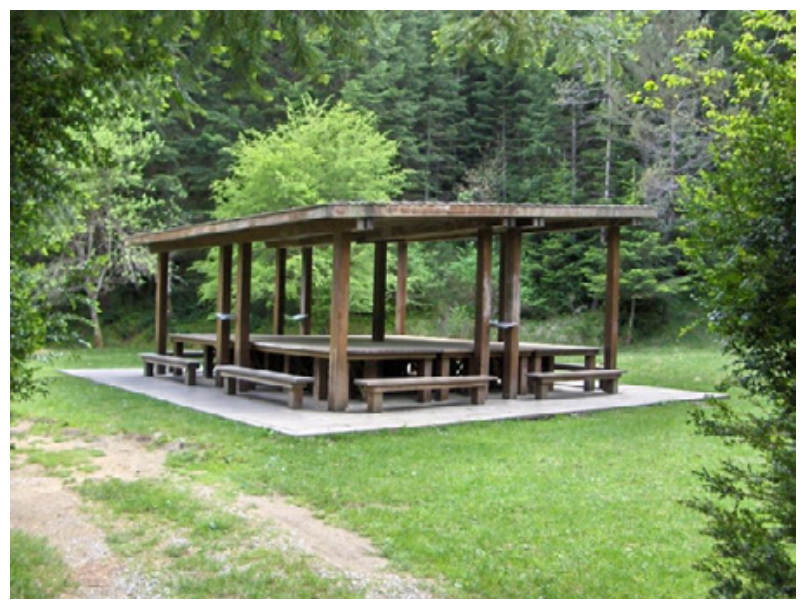

Figura 10: S. Armajani, Mesa de piquenique para Huesca, madeira, acrílico e papel, Valle de Pineta

Créditos: José Guilherme Abreu

${ }_{3}$ Ver https://www.flickr.com/photos/publicartfund/33436432608 
Depois de alguma discussão, chegou-se à conclusão de que faltavam mesas de piquenique. Então, Armajani propôs a Mesa de piquenique para Huesca: uma peça construída inteiramente em madeira de iroko, material que dada a sua dureza e densidade resiste bem ao desgaste e à putrefação. Com capacidade para vinte e cinco utentes (Luesma, 2010, p. 104), a mesa de piquenique de Huesca distingue-se pelo facto de nela ninguém ficar de costas para ninguém, fomentando uma vez mais a interação e a convivialidade entre os utilizadores. Além disso, entre os pilares de apoio da cobertura, protegidos por placas de acrílico, em quatro atris, figuram poemas e pinturas de Frederico García Lorca, poeta e dramaturgo, fuzilado durante a Guerra Civil de Espanha.

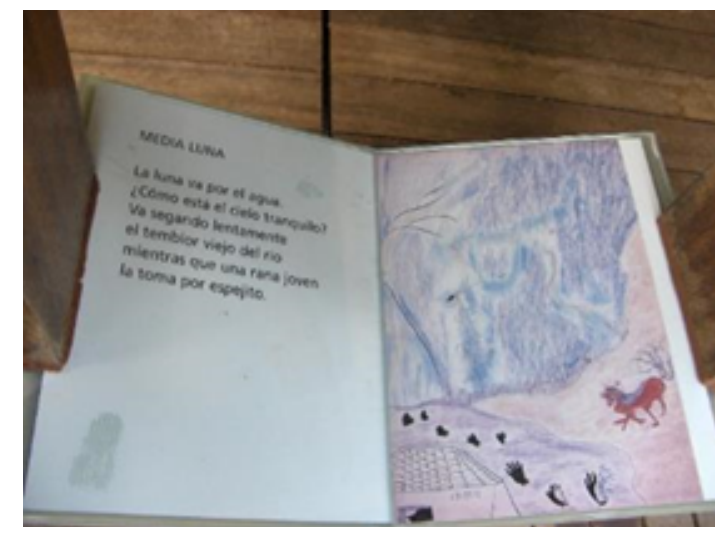

Figura 11: Poema de Frederico García Lorca, integrado na obra Mesa de Piquenique para Huesca (Armajani)

Créditos: José Guilherme Abreu

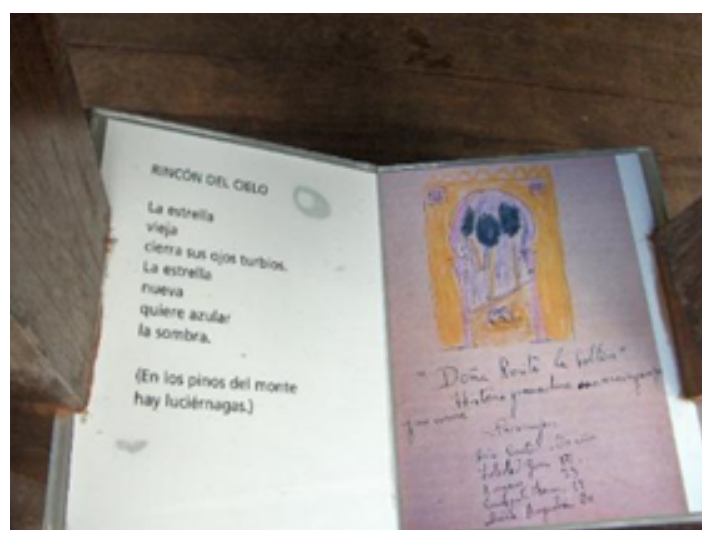

Figura 12: Poema de Frederico García Lorca, integrado na obra Mesa de Piquenique para Huesca (Armajani)

Créditos: José Guilherme Abreu

As duas obras referidas, uma em articulação com o património edificado - a célebre Ponte de Brooklyn - e o outro integrado em pleno património natural, são testemunho do diálogo simbiótico da Arte Contemporânea com o património cultural e natural, e ao mesmo tempo da sua apropriação pública. 
De resto, como costumo assinalar, a obra de Siah Armajani logra resolver o célebre dilema de Arnold Schoenberg, quando este diz: "se é arte, não é para todos, e se é para todos, não é arte" (Schoenberg, 1950, p. 124).

$\mathrm{Na}$ verdade, a produção artística de Siah Armajani logra ser ao mesmo tempo arte, e inclusive arte contemporânea, e arte para todos.

Como obtém o artista esse efeito? Ao promover a apropriação pública da obra pela sua utilização, e ao fomentar simultaneamente a reflexão dos cidadãos, através da colocação de citações de caráter filosófico, literário ou reproduções artísticas, que interpelam o utilizador, para lá do uso literal, ou da mera atividade motora, convidando-os a descobrir os autores desses mesmos registos.

Arte virada ao mesmo tempo para a ação e para a reflexão, as peças de Armajani não são porém nunca retóricas, aspeto que importa salientar. Na verdade, é pela rejeição radical de toda e qualquer retórica que elas manifestam ser obras contemporâneas.

E é também pela rejeição da retórica que a produção artística de Armajani atualiza o ideário progressista e (per)formativo da arte pública que, como vimos, presidiu à sua génese, ao mesmo tempo que descarta a esterilidade retórica de Eugène Broerman, secretário-geral dos congressos internacionais de arte pública, entre 1898 e 1910.

\section{O ideário conceptual de Siah Armajani}

Não é, pois, por acaso, que em Siah Armajani ocorre a superação do dilema de Schoenberg, mas por refletida e consciente opção estética e poética, como o seu manifesto (1995) o comprova.

Texto composto por vinte e seis proposições, o manifesto de Siah Armajani (1995) é uma das reflexões mais desenvolvidas da teoria da arte pública.

Recorremos de novo à metodologia da análise por tópicos, na Tabela 3 (ver Apêndices).

A análise da Tabela 3 deve ser levada a cabo tomando em conta o número de vezes que um dado tópico ocorre e, em simultâneo, considerando a ordem com que o mesmo aparece na tabela. Um tópico aparecer antes (número de preposição inferior) deve ser considerado, em nossa opinião, como prioritário. Um mesmo tópico aparecer em várias preposições deve ser considerado, em nossa opinião, crítico.

Partindo deste pressuposto, isso quer dizer que o aspeto prioritário, por excelência, da teoria da arte pública em Siah Armajani é a assunção do moderno, quando ele diz, no ponto 1, que "a escultura pública é a continuação da lógica do movimento moderno e do iluminismo, temperados e condicionados pela revolução norte-americana" (Armajani, 1995, p. 111).

Da mesma forma, poderemos aduzir que o aspeto crítico, por excelência, da teoria da arte pública em Siah Armajani é a defesa da dimensão social da obra da arte, quando ele diz, por exemplo, no ponto 11, que "a escultura pública não é apenas uma criação artística, mas também uma produção social e cultural baseada em necessidades concretas" (Armajani, 1995, p. 112), sendo essa premissa repetida de diferente modo noutras preposições. 
Particular destaque deve ser dado à questão "Mito do criador" que aparece em segundo lugar no enunciado e que é reiterado três vezes.

Eis um resultado possível, que corresponde à elaboração de uma síntese do texto, e que a título de exemplo elaboro para aqui: a escultura pública democrática "assume a modernidade", ao mesmo tempo que "relativiza a autoria". Visando explorar a dimensão social da arte, a escultura pública democrática "recusa a autorreferencialidade da obra de arte", e simultaneamente "rejeita a especificidade de sítio". Sendo uma "arte pensada para todos", a escultura pública democrática é uma "arte não pretensiosa" que visa a "partilha de valores éticos", e que se apresenta como "arte disponível e útil". Permanecendo "independente face à arquitetura", a escultura pública democrática descarta a utilização "para fins de propaganda" e mantém-se permanentemente "aberta à opinião pública" (Abreu, 2019).

Apesar de se conceber como rigorosa e isenta, esta perspetiva de análise é obviamente estabelecida a partir de um dado ponto de vista, aspeto que não pode ser escamoteado.

Seja como for, a partir desta análise e da respetiva síntese, ficam estabelecidos os eixos fundamentais da teoria da arte pública de Siah Armajani, e facilitada a sua compreensão, ao mesmo tempo que se torna possível confrontar o enunciado teórico com a produção artística, desenvolvida a partir da disciplina praticada pelo autor: a escultura pública.

\section{Siah Armajani vs Richard Serra?}

Terminamos o presente estudo com a referência a uma obra de Armajani que não sendo uma obra instalada no espaço público, curiosamente, não deixa de refletir a mesma preocupação para com a esfera pública.

Trata-se da peça Fallujah cujo título alude a uma cidade do Iraque, situada na proximidade da cidade de Abu Ghraib, onde se situava a sinistra prisão do mesmo nome.

$\mathrm{Na}$ noite de 28 de abril de 2003 uma multidão de duzentas pessoas desafiou um toque de recolher imposto pelos militares americanos, e reuniu-se diante de uma escola secundária usada como quartel-general militar, exigindo a sua reabertura. Os soldados da $82^{a}$ Divisão Aérea disparam contra a multidão, tendo provocado dezassete mortos e setenta feridos.

Um protesto contra as mortes realizado dois dias mais tarde também terminou em conflito com forças americanas, onde duas pessoas morreram, vítimas de disparos.

Em 31 de março de 2004, revoltosos iraquianos em Fallujah fizeram uma emboscada a um comboio que continha quatro militares contratados pela empresa Blackwater USA, o que provocou uma operação das forças armadas americanas para retomar o controlo da cidade. Essa operação saldou-se em milhares de mortos. 


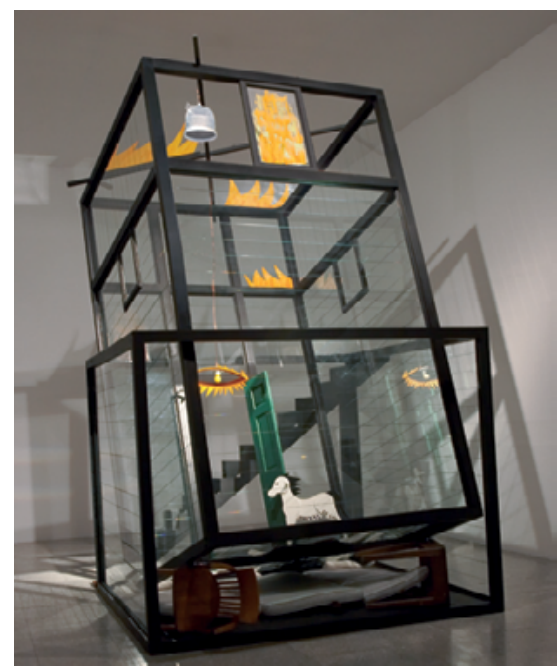

Figura 13: Armajani (2007), "Fallujah", Artium, Vitória Fonte: Raverty (2007, n. p.)

Terminada em 2005, a peça de Siah Armajani foi exposta ao público, pela primeira vez, no Museo de Arte Contemporâneo de Vitória, no País Basco, não só porque a sua exposição tinha sido proibida nos Estados Unidos durante a Presidência de George W. Bush, mesmo numa galeria privada, de acordo com a seguinte notícia:

há 70 anos, um día como hoje, a aviação nazi que apoiava os rebeldes com o general Franco bombardeou Gernika, inaugurando a infame lista de ataques aéreos indiscriminados contra a população civil. Picasso pintou como denúncia daquele crime Guernica, uma das obras de arte que meIhor refletem a barbárie humana. Ontem inaugurou-se no Artium a exposição Fallujah, do artista iraniano Siah Armajani, obra que bebe do quadro de Picasso e que denuncia outro ato de guerra: o bombardeamento dessa cidade iraquiana pelo exército dos EUA, em que morreram 6.000 civis. A inauguração de Fallujah no Artium supõe também a apresentação internacional da obra que Siah Armajano terminou em 29 de agosto de 2005. A censura que se vive nos Estados Unidos com tudo o que se refere à guerra no Iraque impediu que este criador iraniano residente no país americano tenha podido apresentar a sua obra, nem mesmo numa galeria de arte privada. (Crespo, 2007)

$\mathrm{Na}$ presente instalação, Armajani representa una casa pequena, de dois andares, o segundo derrubado sobre o primeiro, abatido sobre os objetos e as pessoas que se encontravam no dormitório. Um cavalinho de baloiço, uma carpete, uma jaula vazia e outros objetos de uso quotidiano completam o cenário, emprestando uma nota dramática à obra, que se reforçam de resto com inequívocas alusões à conhecida tela de Picasso sobre o bombardeamento da cidade de Guernica pela aviação nazi, situada a escassas dezenas de quilómetros do Atrium. 
Apesar de não se encontrar implantada no espaço público, não será legítimo considerar esta uma obra de arte pública, ainda assim? Não preenche a mesma os requisitos previamente formulados por Siah Armajani para definir o que deve ser uma obra de escultura pública?

Sobre a proibição que pendeu sobre esta peça durante a presidência de George W Bush, Siah Armajani pronunciou-se como se segue:

Durante toda a minha vida artística contei com facilidade para expor o meu trabalho, mesmo quando era jovem. Agora aos 68 anos, tive que pedir ajuda a amigos espanhóis para poder apresentar o meu trabalho. (Siah Armajani, citado em Crespo, 2007)

A oposição à exibição de Fallujah numa galeria de arte privada, para nós reveste-se de uma particular relevância teórica. É que a mesma vem demonstrar algo que há muito vimos defendendo: não é o direito de propriedade que atribui (ou retira) à obra de arte a qualidade de ser entendida como obra de arte pública.

Além desse ponto, que não é de somenos, esta peça introduz um outro aspeto que importa destacar: ela dialoga com o património, na medida em que se concebe na adoção de traços da iconografia/simbólica da Guernica de Picasso.

De resto, as peças de Siah Armajani integram-se no Património, em vez de se oporem a ele. Ponte sobre Árvore dialoga com o património histórico monumental (Brooklyn Bridge). A Mesa de Piquenique para Huesca, integra-se no património natural do Vale de Pineta, nos Pirenéus aragoneses, e o Jardim de Estudo ${ }^{4}$, instalação com que Armajani participou no "Skulptur Projekt Munster" de 1987, integra-se no património edificado.

Esta instalação permanente insere-se no ciclo "Espaços de Leitura", cujas peças e maquetas Siah Armajani apresentou em 1995, em Barcelona, no MACBA, sendo precisamente no catálogo dessa exposição que publicou o seu manifesto.

Como contraprova, poderíamos invocar o caso do Tilted Arc ${ }^{5}$, de Richard Sierra que sendo uma obra inserida no programa federal de Arte Pública do General Services Administration (GSA), e porque o mesmo não se enquadra dentro dos parâmetros do conceito de arte pública exarados no manifesto de Siah Armajani, dificilmente pode ser reconhecido como uma obra exemplar de arte pública.

O Tilted Arc não pode considerar-se uma obra de arte pública, pelo menos ao abrigo do que se encontra definido como tal, no "Manifesto public sculpture in the context of american democracy" (Armajani, 1995), já que viola claramente três dos seus tópicos definidores, a saber, os tópicos relativização da autoria; recusa da autorreferencialidade da obra de arte; rejeição da especificidade do sítio, e outros, além destes, poderiam ser de igual modo legitimamente invocados.

Não será, pois, de admirar que um dia a peça Fallujah ainda venha ser instalada no espaço público, para lembrar o período negro da História norte-americana, vivido

\footnotetext{
${ }^{4}$ Ver https://www.skulptur-projekte-archiv.de/en-us/1987/projects/6/

${ }_{5}^{5}$ Ver https://d2jv9oo3bew7ag.cloudfront.net/uploads/Richard-Serra-Tilted-Arc.jpg
} 
imediatamente a seguir ao infame ataque terrorista de 11 de setembro de 2001 às Torres Gémeas, e que teima a reeditar-se, na atualidade.

\section{ILAÇÕES FINAIS}

O itinerário artístico e conceptual de Siah Armajani permite-nos retirar um conjunto de ilações finais que nos parecem particularmente relevantes, tal como passamos a enumerar:

- uma obra de arte pública contemporânea não tem necessariamente de se conceber como conceptualmente oposta ou incompatível com o património histórico-cultural. O caso de Siah Armajani é a esse título eloquente, não porque ao nível da sua produção artística algumas das suas obras mais notáveis coabitam simbioticamente com o património histórico e até monumental, como também no plano da sua produção teórica se verifica a consonância do ideário que professa, com o ideário do movimento em prol da arte pública surgido nos finais do século XIX, como vimos;

- uma obra de arte pública contemporânea não adquire a qualidade de poder considerar-se "pública" só porque se apresenta colocada no espaço público. Existem inúmeras peças que nunca foram pensadas para figurarem no espaço público que são por direito irrefutável obras de arte pública. $O$ caso da tela Guernica de Picasso e da instalação Fallujah de Siah Armajani, são exemplos flagrantes dessa circunstância;

- tal como a implantação no espaço público não é critério para conferir o estatuto de obra pública a uma obra de arte, também o critério do financiamento não é suficiente para conferir o estatuto de obra pública a uma obra financiada com dinheiros públicos. Existem obras financiadas por fundos particulares que não deixam por isso de ser obras públicas, como acontece com as obras de arte integradas na arquitetura privada em edifícios abertos ao uso público, como por exemplo em bancos, universidades privadas ou centros comerciais. E claro está, da mesma forma não devem também considerar-se obras de arte pública, todas aquelas que apesar de financiadas por dinheiro público, violem os valores da democracia e da fraternidade;

- não é porque uma estátua é figurativa ou apologética que automaticamente a mesma pode ser considerada de propagandística e, como tal, obsoleta. Não há à partida tipologias escultóricas ou modelos pictóricos bons e tipologias escultóricas ou modelos pictóricos maus. O que há é conteúdos e/ou funções compatíveis ou incompatíveis com a cidadania democrática e a convivialidade cívica.

De todos os critérios o da cronologia é o mais falível, como demonstrou Georges Didi-Huberman em Devant le temps: histoire de l'Art et l'anachronisme des images (2000), depois de surpreender nos painéis inferiores do fresco Madona delle Ombre de Fra Angelico, datado de meados do século XV, inequívocas conotações com a pintura gestual de Jackson Pollock, que viria a afirmar-se internacionalmente, em meados do século XX, no segundo pós-guerra.

\section{REFERÊNCIAS}

Abreu, J. G. (2010). El concepto de arte público. Sus orígenes y significado actual. In B. G. Vega, M. B. Balbás \& J. P. L. Lorente (Eds.), Arte público hoy. Nuevas vías de consideración y interpretación crítica. Actas del congreso internacional de críticos de arte (pp. 17-29). Burgos: AECA/ACYLCA.

Abreu, J. G. (2013). Arte pública. Origens e condição histórica. In Actas do colóquio internacional arte pública e envolvimento comunitário (pp. 17-37). Porto: Universidade Católica Editora. 
Abreu, J. G. (2015). A arte pública e as suas especificidades. In M. Á. C. Martin (Ed.), Ciudad y artes visuales (pp. 43-55). Madrid: Grupo de Investigación Arte, Arquitectura y Comunicación en la Ciudad Contemporánea, Universidade Complutense de Madrid.

Abreu, J. G. (2018). A arte pública como meio de interaç̧ão social: da participação cívica ao envolvimento comunitário. In B. P. de Almeida, C. Rosendo \& M. B. Alves (Eds.), Arte pública. Lugar, contexto, participação (pp. 167-183). Lisboa: IHA-FCSH, Universidade Nova de Lisboa e Câmara Municipal de Santo Tirso.

Abreu, J. G. (2019). Lecture texts. Porto: UCP.

Armajani, S. (1995). Manifesto public sculpture in the context of american democracy. In G. Picazo (Ed.), Espacios de lectura/reading spaces (pp. 111-114). Barcelona: Consorci del Museu d'Art Contemporani de Barcelona.

Broerman, E. (1895). L'art appliqué à la rue et aux objets d'utilité publique. Bruxelas: Alfred Castaigne Éditeur.

Broerman, E. (Ed.) (1907). L'art public. Revue International d'Art Public, 1.

Broerman, E. et. al. (1898). Premier congrès international de l'art public tenu à Bruxelles du 24 au 29 septembre 1898. Bruxelas: Académie Royale des Beaux-Arts.

Broerman, E. et. al. (1905). Ille congrès international de l'art public tenu à Liège 12-21 Septembre 1905. Bruxelas: Académie Royale des Beaux-Arts.

Broerman, E. et. al. (1910). IVe congrès international de l'art public. Rapports et compte-rendus. Bruxelas: Académie Royale des Beaux-Arts.

Crespo (2007, 26 de abril). Txema G., Siah Armajani exhibe en el artium su denuncia del ataque norteamericano a civiles en Irak. El País. Retirado de https://elpais.com/diario/2007/04/26/ paisvasco/1177616414_850215.html

Didi-Huberman, G. (2000). Devant le temps: histoire de l'art et l'anachronisme des images. Paris: Les Éditions di Minuit.

Elliott, D. (1979). Rodchenko and the arts of revolutionary Russia. Oxford: Museum of Modern Art.

Johnstone, M. (2018). The freemasons: the ancient brotherhood revealed. Londres: Arcturus Publishing Limited.

Luesma, T. (2010). Arte público: paisaje, arte y naturaleza. In B. G. Vega, M. B. Balbás \& J. P. L. Lorente (Eds.), Arte público hoy. Nuevas vías de consideración y interpretación crítica. Actas del congreso internacional de críticos de arte (pp. 101-110). Burgos: AECA/ACYLCA.

Mechlin, L. (1922). Art life in Washington. Records of the Columbia Historical Society, 24, 164-191.

Museo Nacional Centro de Arte Reina Sofía. (2000). Siah Armajani [Exposição]. Madrid. Retirado de https:// www.museoreinasofia.es/en/exhibitions/siah-armajani

Raverty, D. (2007). Siah Armajani: Fallujah and other recent glass constructions. Sculpture Magazine, 26(10). Retirado de https://www.sculpture.org/documents/scmago7/dec_07/armajani/armajani.shtml

Return to exile Siah Armajani. (2010, julho/agosto). ArtAsiaPacific Magazine, 69. Retirado de http:// artasiapacific.com/Magazine/69/ReturnToExileSiahArmajani

Resseler, M. (2013). Brussels 1893. The origins of an aesthetic revolution. Art Nouveau, 5(9/10), 92-95.

Schoenberg, A. (1950). Style and ideas. Selected writings. Nova lorque: Philosophical Library. 
Shaw, E. (1970). Computer print-out makes nine feet column in museum show. Nova lorque: MoMA.

Smets, M. (1995). Charles Buls. Les principes de l'art urbain. Liège: Mardaga.

Tomkins, C. (1990, 19 de março). Open, available, useful. New Yorker, 52-54.

\section{ApÊNDICES}

\begin{tabular}{|c|c|c|c|}
\hline Artigos & AssunTos & $\mathbf{N}^{\mathbf{O}}$ DE $\int$ & TEOR \\
\hline Art. $1^{\circ}$ & Objetivos do IIAP & 3 & $\begin{array}{l}\text { Difundir a arte pública na teoria e na prática; concretizar as deci- } \\
\text { sões dos congressos de arte pública; preparar os congressos in- } \\
\text { ternacionais de arte pública; editar um boletim periódico }\end{array}$ \\
\hline Art. $2^{\circ}$ & Sede e secções do IIAP & 7 & $\begin{array}{l}\text { Sediado em Bruxelas; dividido em sete secções: educação estética } \\
\text { (escola e família); educação especial (escolas técnicas; profissionais } \\
\text { e industriais); museus e exposições; teatro, espetáculos e festas; as- } \\
\text { peto das cidades, vilas e paisagens; legislação e regulamentação pro- } \\
\text { tetora da arte pública; documentação, bibliografia e iconografia; }\end{array}$ \\
\hline $\operatorname{Art} .3^{\circ}$ & Tutela e membros & 1 & $\begin{array}{l}\text { Tutela dos estados, províncias e cidades aderentes; composi- } \\
\text { ção: membros de honra (chefes de estado, membros protetores, } \\
\text { membros efetivos; conselho permanente de } 40 \text { membros; }\end{array}$ \\
\hline Art. $4^{\circ}$ & Órgãos executivos do IIAP & 1 & Colégio internacional e Conselho permanente \\
\hline Art. $5^{\circ}$ & Colégio internacional & 1 & $\begin{array}{l}\text { Colégio internacional (assuntos gerais; delegados, mem- } \\
\text { bros efetivos, duração mandatos seis anos, presiden- } \\
\text { te, vice-presidente e secretário-geral, cotizações) }\end{array}$ \\
\hline Art. $6^{\circ}$ & Administração e direção & 1 & $\begin{array}{l}\text { Conselho permanente de } 40 \text { membros belgas, nomeados pelo Colégio } \\
\text { internacional; comissão administrativa; duração dos mandatos seis anos. }\end{array}$ \\
\hline Art. $7^{\circ}$ & Colégio internacional & 1 & $\begin{array}{l}\text { De dois em dois anos. Fixa o local e a data dos congressos inter- } \\
\text { nacionais e assembleias gerais dos membros do instituto }\end{array}$ \\
\hline Art. $8^{\circ}$ & Recursos do IIAP & 3 & $\begin{array}{l}\text { Cotizações dos membros protetores e membros efetivos: sub- } \\
\text { venções dos estados; doações, legados, direitos, etc. }\end{array}$ \\
\hline Art. $9^{\circ}$ & Boletim do IIAP & 1 & $\begin{array}{l}\text { Publica informações e documentos com interesse para cada sec- } \\
\text { ção e para todos os países sobre o instituto e a sua obra }\end{array}$ \\
\hline Art. $10^{\circ}$ & Alteração dos estatutos & 1 & $\begin{array}{l}\text { Podem ser alterados pelo Colégio internacional depois de ouvi- } \\
\text { do o Conselho permanente. As alterações devem ser propostas à } \\
\text { Comissão administrativa com seis meses de antecedência }\end{array}$ \\
\hline Art. $11^{\circ}$ & $\begin{array}{l}\text { Condições de dis- } \\
\text { solução do IIAP }\end{array}$ & 1 & $\begin{array}{l}\text { A dissolução do IIAP deve ser decidida em documento assina- } \\
\text { do por pelo menos um quarto dos membros do instituto }\end{array}$ \\
\hline Art. $12^{\circ}$ & Dissolução (ativos) & 1 & $\begin{array}{l}\text { Após a dissolução os ativos do instituto devem ser afe- } \\
\text { tados a obras de educação artística }\end{array}$ \\
\hline
\end{tabular}

Tabela 1: Estatutos do Instituto Internacional de Arte Pública (IIAP)

Fonte: Broerman, 1907 


\begin{tabular}{|c|c|c|c|}
\hline AssunTos & TÍTULOS & AUTORES & EXCERTOS \\
\hline Edital & $\begin{array}{l}\text { A arte } \\
\text { pública }\end{array}$ & $\begin{array}{l}\text { Eugène } \\
\text { Broerman }\end{array}$ & $\begin{array}{l}\text { Os monumentos comemorativos, os viadutos, as edículas e os objetos de } \\
\text { utilidade pública: quiosques, fontes, candeeiros, bancos, caixas de correio, } \\
\text { postos telefónicos, mostradores elétricos, sinalética, etc., de-vem ser obras } \\
\text { de arte, tal como os quadros e as estátuas para os museus, onde entram } \\
\text { apenas as obras dignas de aí figurar, apesar de esse destino desviar a arte } \\
\text { da sua missão social, enquanto na rua e nos monumentos civis e religio- } \\
\text { sos - museus da vida pública - se toleram ainda formas vulgares. (p. 5) }\end{array}$ \\
\hline \multirow{4}{*}{$\begin{array}{l}\text { Tradições } \\
\text { nacionais }\end{array}$} & $\begin{array}{l}\text { Provença } \\
\text { (soneto) }\end{array}$ & $\begin{array}{l}\text { Frédéric } \\
\text { Mistral }\end{array}$ & $\begin{array}{l}\text { Provença, tu também, sem dinheiro, sem exército - /Nada a não ser para a tua beleza, } \\
\text { nada a não ser para ser amada /- Tu serás para sempre a Rainha do Sol (p. 11) }\end{array}$ \\
\hline & $\begin{array}{l}\text { A cidade } \\
\text { de Paris } \\
\text { e a arte } \\
\text { pública no } \\
\text { século XVI }\end{array}$ & $\begin{array}{l}\text { Marius } \\
\text { Vachon }\end{array}$ & $\begin{array}{l}\text { Desde sempre - pelo menos a partir do século XIII - a administração municipal da ci- } \\
\text { dade de Paris contou com um funcionário tendo entre as suas atribuições uma espécie } \\
\text { de serviço de arte pública, para a construção e vigilância das construções municipais, } \\
\text { serviço ao qual estava anexada a manutenção das ruas e das praças. Este funcionário } \\
\text { tinha o título de "Mestre das obras de alvenaria e pavimentação da cidade". (p. 15) }\end{array}$ \\
\hline & Pela beleza & $\begin{array}{l}\text { Carmen } \\
\text { Sylva }\end{array}$ & $\begin{array}{l}\text { Para isso que a beleza seja compreendida e concebida por aqueles que pro- } \\
\text { curarão exprimi-la no seu trabalho. Assim, eles dedicar-se-ão a contribuir } \\
\text { para o embelezamento social e realizarão pela educação pública, de que são } \\
\text { os obreiros, os votos unânimes dos congressos de arte pública. (p. 24) }\end{array}$ \\
\hline & $\begin{array}{l}\text { A educação } \\
\text { artística } \\
\text { nacional }\end{array}$ & Water Crane & $\begin{array}{l}\text { Na sua associação com a vida humana, nós vemos talvez a mais importante função } \\
\text { da arte na sua divulgação pública, permeando a socialização e o espírito refinado da } \\
\text { beleza e harmonia da vida e do aspeto das nossas cidades. Nesta direção há de facto } \\
\text { mito para se fazer em todos os países e é nesta base que todos os pontos de vista da } \\
\text { arte parecem unir-se - educacional, histórico, técnico, imaginativo, monumental. Aqui, } \\
\text { nós temos de educar o economista, o sanitário, o utilitário, e lutar contra o estreito } \\
\text { e sórdido espírito comercial, que apenas pensa no benefício monetário imediato, e } \\
\text { esquece o vasto e mais verdadeiro investimento nacional- o bem-estar do povo, e o } \\
\text { enriquecimento da vida pública, fazendo da beleza uma aquisição comum. (p. 26) }\end{array}$ \\
\hline \multirow{2}{*}{$\begin{array}{l}\text { Salvaguarda } \\
\text { dos sítios e } \\
\text { patrimónios } \\
\text { artísticos }\end{array}$} & $\begin{array}{l}\text { A ressur- } \\
\text { reição de } \\
\text { Herculanum }\end{array}$ & $\begin{array}{l}\text { H. Carlon } \\
\text { de Wiart }\end{array}$ & $\begin{array}{l}\text { Charles Waldstein, que dirigiu importantes escavações em Platea, Erétria, Sícion, Es- } \\
\text { parta, Argos, e que ensina há vinte e sete anos na Universidade de Cambridge, perten- } \\
\text { ce a essa estirpe americana para quem os obstáculos não passam de encorajamentos } \\
\text { à ação. Decidiu provocar um entendimento internacional cujo objeto seria a ressurrei- } \\
\text { ção de Herculanum. Uma tal empresa, dizia ele, exigiria grandes despesas, pelo que } \\
\text { seria injusto impor o seu encargo apenas à Itália. Por outro lado, convinha que este } \\
\text { país tivesse na organização e execução do projeto uma parte preponderante. (p. 30) }\end{array}$ \\
\hline & $\begin{array}{l}\text { As ardenas } \\
\text { e a gruta } \\
\text { de Hans }\end{array}$ & $\begin{array}{l}\text { Ed. De } \\
\text { Pierpont }\end{array}$ & $\begin{array}{l}\text { A comovente montanha escavada com os seus movimentos interiores con- } \\
\text { gelados esconde construções fantásticas ornamentadas de estalactites dia- } \\
\text { mantíferas, obras decorativas magicamente originais realizadas pela gota de } \\
\text { água e pelo tempo, em formas equilibradas, amplas, verdadeiros modelos de } \\
\text { ornamentação proporcionada. Mas é necessário ver essas salas como elas } \\
\text { são: as débeis tochas não permitiam deixá-las revelar-se ... isso foi o resultado } \\
\text { da iluminação elétrica, problema ingrato, gloriosamente resolvido (p. } 36)\end{array}$ \\
\hline
\end{tabular}




\begin{tabular}{|c|c|c|c|}
\hline & $\begin{array}{l}\text { As transfor- } \\
\text { mações de } \\
\text { Bruxelas }\end{array}$ & $\begin{array}{l}\text { L. Dumont- } \\
\text {-Wilden }\end{array}$ & $\begin{array}{l}\text { Ao mesmo tempo que os que lhes as ordenam [as cidades] desenham esses cordões } \\
\text { retilíneos que as vias traçam através das casas, eles creem ser indispensável de arran- } \\
\text { jar nessa acumulação de pedras um oásis de verdura que nos faça lembrar o esplendor } \\
\text { variegado dos bosques. Mas é o centro da cidade que, por norma, é o único que be- } \\
\text { neficia da doçura dos parques urbanos. A periferia das grandes cidades é geralmente } \\
\text { desprovida da alegria do frondoso, e as aglomerações criadas bruscamente pela cen- } \\
\text { tralização social são rodeadas de imensos e leprosos arrabaldes. É o esforço de todos } \\
\text { aqueles que se interessam pela beleza e pela salubridade citadinas de arejar, de clarear, } \\
\text { de embelezar esses subúrbios durante tanto tempo deixados ao abandono. (p. 39) }\end{array}$ \\
\hline & $\begin{array}{l}\text { Da cons- } \\
\text { trução mo- } \\
\text { derna das } \\
\text { cidades na } \\
\text { Alemanha }\end{array}$ & J. Siebben & $\begin{array}{l}\text { Do ponto de vista da arte, a qualidade essencial das praças libres encontra-se no } \\
\text { seu enquadramento; o enquadramento é uma necessidade imperiosa para as praças } \\
\text { do mercado, para as praças com jardim e sobretudo para as praças monumen- } \\
\text { tais, quer dizer destinadas a receber edifícios e motivos de arquitetura. A melhor } \\
\text { implantação dos edifícios e dos motivos é na periferia da superfície livre, e não } \\
\text { na praça em si mesma; no último caso as considerações de enquadramento e de } \\
\text { escala aplicam-se ao que fica da praça. Para completar o enquadramento utiliza-se } \\
\text { muitas vezes portas (portas das cidades, arcos-de-triunfo, arcadas sobrepujadas de } \\
\text { construções ou motivos esculturais) ou pórticos e arcadas delimitando as esquinas } \\
\text { das ruas. É necessário evitar erros de escala, e evitar sobretudo os espaços dema- } \\
\text { siado estendidos. Ao nivelamento convexo de uma praça, preferir-se-á a superfície } \\
\text { côncava. Cada praça deve ser tratada à parte, tanto quento possível. (p. 48) }\end{array}$ \\
\hline \multirow[t]{2}{*}{$\begin{array}{l}\text { Evolução } \\
\text { artística das } \\
\text { cidades }\end{array}$} & $\begin{array}{l}\text { O desen- } \\
\text { volvimento } \\
\text { artístico } \\
\text { das cidades } \\
\text { americanas }\end{array}$ & $\begin{array}{l}\text { Glenn } \\
\text { Brown }\end{array}$ & $\begin{array}{l}\text { O modelo do Mall que oferece a reintegração e desenvolvimento do desenho de Pierre } \\
\text { l'Enfant, demonstra o que pode ser feito pela franqueza, simplicidade e dignidade } \\
\text { no tratamento e agrupamento de estruturas clássicas. A composição contempla dois } \\
\text { eixos principais, um leste e oeste que começa com o Capitólio e deixa como elemento } \\
\text { central o Monumento a Washington, terminando com o Memorial Lincoln; o outro, } \\
\text { que começa pela Casa Branca, e tem como elemento central o Jardim do Monumento, } \\
\text { terminando com o Monumento aos criadores da Constituição. O ajardinamento e } \\
\text { as veredas do parque, os adornos arquitetónicos e o fornecimento de novos pré- } \\
\text { dios foram projetados para aprimorar as dimensões do Capitólio, da Casa Branca, } \\
\text { do Monumento a Washington, do Lincoln Memorial e o Memorial da Constituição } \\
\text { que são os principais pontos de interesse e beleza na composição. (p 52-53) }\end{array}$ \\
\hline & $\begin{array}{l}\text { O papel } \\
\text { da crítica } \\
\text { de arte }\end{array}$ & $\begin{array}{l}\text { Frantz } \\
\text { Jourdain }\end{array}$ & $\begin{array}{l}\text { As nossas avenidas, os nossos cruzamentos, as nossas praças são desonradas } \\
\text { por monumentos agressivos que os hotentotes não querem; o Sr. Puech, que se } \\
\text { enfurece contra nós sem piedade, conseguiu relegar o marechal Ney, de Rude, } \\
\text { para um canto escuro e colocar no lugar desta obra-prima radiante sua escul- } \\
\text { tura assustadora. Aqui está o bobo Alfred de Musset da Comédie Française; ali } \\
\text { o grotesco Chappe do Boulevard Saint-Germain; mais adiante fica a lanterna } \\
\text { de Shakespeare, na avenida Malesherbes, a estreita Jeanne d'Arc de Dubois, } \\
\text { o surpreendente Victor Hugo de Barrias e, finalmente, o Monumento Garnier, } \\
\text { cujo belo busto de Carpeaux se transformou numa rolha de garrafa e cujo dou- } \\
\text { rado ofuscante e selvagem evoca a lembrança de um pesadelo de zinco. } \\
\text { E contra estes horrores, as críticas não emitiram um único grito de indig- } \\
\text { nação e raiva, nem um homem de letras reivindicou a escolha vingativa } \\
\text { dos demolidores! Sorrimos, aplaudimos e passamos com pressa para con- } \\
\text { cluir um caso lucrativo de publicidade com um negociante de arte ou um } \\
\text { amador ansioso para liquidar sua galeria pelos preços mais altos. } \\
\text { Críticas informadas e inteligentes podem ter uma influência significativa na precisão da } \\
\text { visão e na produção artística de uma época. Um esforço energético ainda nos salvaria } \\
\text { do desconforto que nos envolve. Esperemos que a imprensa retome a tradição do pas- } \\
\text { sado e entenda, finalmente, que sua verdadeira missão é a educação do povo. (p. 55) }\end{array}$ \\
\hline
\end{tabular}




\begin{tabular}{|c|c|c|c|}
\hline \multirow{5}{*}{$\begin{array}{l}\text { A cultura } \\
\text { estética }\end{array}$} & $\begin{array}{l}\text { A imagem } \\
\text { na escola }\end{array}$ & A. Stuys & $\begin{array}{l}\text { Por aplicação de um desejo da III Congresso de arte pública, foi constituída } \\
\text { na cidade de Bruxelas, há alguns meses, uma Comissão encarregada de es- } \\
\text { colher cerca de vinte locais pitorescos e característicos do país; artistas serão } \\
\text { responsáveis pelas executar; A litografia De Rycker e Mendel as reproduzi- } \\
\text { rão em formato grande e colorido, e que serão vendidas a preços baixos. } \\
\text { Todas as escolas em breve poderão colocar sob os olhos dos alunos belas represen- } \\
\text { tações artísticas dos vários aspetos da terra natal. Três conselhos já foram aprovados } \\
\text { pela Comissão: dois de Cassiers (uma fazenda flamenga perto de Bruges, a praia) e } \\
\text { um de F. Toussaint (Meuse a jusante de Dinant). Depois vêm as vistas de Bruxelas, } \\
\text { Bruges, Gante, Antuérpia, Liège, Campine, Ardenas, região industrial, etc. (p. 6o) }\end{array}$ \\
\hline & $\begin{array}{l}\text { Ensino } \\
\text { da arte } \\
\text { industrial } \\
\text { na Holanda }\end{array}$ & $\begin{array}{l}\text { M. von } \\
\text { Saher }\end{array}$ & $\begin{array}{l}\text { Os professores são quase todos homens do ofício: arquitetos, esculto- } \\
\text { res, decoradores, metalúrgicos, etc., e ensinam na escola dois dias por se- } \\
\text { mana, os outros dias eles trabalham com os alunos nas oficinas. } \\
\text { Dessa forma, ficam asseguradas as relações da escola com o atelier. } \\
\text { O objetivo do programa é desenvolver a técnica do artesanato e permitir que o } \\
\text { artesão encontre novas formas, dececionar inspirado pela natureza, respondendo } \\
\text { ao assunto e à matéria praticada. As altas conceções da arte antiga também são } \\
\text { cultivada. Os estudantes que saem da escola têm grande demanda em oficinas } \\
\text { e muitos deles ocupam lugares distintos no ensino de artes e ofícios. (p. 61) }\end{array}$ \\
\hline & $\begin{array}{l}\text { O canto } \\
\text { popular }\end{array}$ & $\begin{array}{l}\text { Florimond } \\
\text { Van Dayse }\end{array}$ & $\begin{array}{l}\text { Os Liederavonden, desde a sua criação em Ghent, foram organizados em An- } \\
\text { tuérpia, em várias outras cidades do nosso país e na Holanda. Eles são cer- } \\
\text { tamente uma das melhores maneiras de desenvolver na classe trabalhadora } \\
\text { o senso moral e o sentimento artístico, e deve contribuir efetivamente para a } \\
\text { preservação da língua materna, a manutenção do gênio nacional. (p. 67) }\end{array}$ \\
\hline & $\begin{array}{l}\text { Curso de } \\
\text { rstética }\end{array}$ & Mario Pilo & $\begin{array}{l}\text { A arte será, portanto, feita por todos, significa que será feita para todos: as mesmas } \\
\text { razões económicas e psicológicas, de liberdade... pelo menos a maior parte do dia, } \\
\text { de igualdade ... pelo menos diante das primeiras necessidades, até estética, da } \\
\text { vida e da irmandade ... pelo menos no desejo de que o prazer de alguém cresça, de } \\
\text { rebote, como prazer para os outros, pelas mesmas razões, portanto, exigem que toda } \\
\text { arte esteja à disposição e seja feita em benefício de todos os homens: construções } \\
\text { mais bonitas e mais monumentais, assim como as catedrais e os palácios reais, } \\
\text { agora serão as casas das pessoas, os municípios, as escolas, as galerias, merca- } \\
\text { dos, estações, edifícios públicos de todos os tipos; e as menores, mas não menos } \\
\text { confortáveis e felizes, serão as pequenas casas para uma família cada. (p. 74) }\end{array}$ \\
\hline & $\begin{array}{l}\text { Carta do } \\
\text { síndico de } \\
\text { Florença }\end{array}$ & J. Niccolini & $\begin{array}{l}\text { Florença é representada pelo seu Síndico ao Colégio Internacional do Ins- } \\
\text { tituto de Arte Pública, com a esperança de que o Instituto, agindo sob os } \\
\text { auspícios que valem as promessas mais vinculantes, levante poderosamen- } \\
\text { te a voz para as novas necessidades da arte, para que todas as produções } \\
\text { da civilização moderna ganhem vida com um novo fôlego revigorante. } \\
\text { Florença, que em outros momentos esteve à frente dessa grande evolução das } \\
\text { artes e das letras que iluminam o mundo, vê com a maior satisfação o encontro das } \\
\text { forças vivas das nações civilizadas, para reagir contra o mundano na vida moderna } \\
\text { e direcionar sua atividade criativa para os mais puros fundamentos do Belo. (p. } 76)\end{array}$ \\
\hline
\end{tabular}

Tabela 2: Excertos de artigos da revista do Instituto Internacional de Arte Pública

Fonte: Broerman, 1907 


\begin{tabular}{lll}
\hline \multicolumn{1}{c}{ CLASSES DE TóPICOS } & NÚMERO DAS PROPOSIÇÕES & PONTO DE VISTA DEFENDIDO SOBRE O TÓPICO \\
\hline Modernidade & 1 & Assunção do moderno \\
\hline Mito do criador & $2,3,12$ & Relativização da autoria \\
\hline Dimensão Social & $4,6,9,11$ & Recusa da autorreferencialidade da obra de arte \\
\hline Contexto espacial/lugar & $5,10,16$ & Rejeição da especifidade do sítio \\
\hline Cidadania & $7,22,24$ & Arte pensada para todos \\
\hline Domínio estético & $8,13,23$ & Arte não pretensiosa \\
\hline Dimensão ética & 14 & Partilha de valores éticos \\
\hline Funcionalidade & 15,25 & Arte disponível e útil \\
\hline Relação com a arquitetura & $17,18,19$ & Independência face à arquitetura \\
\hline Grandes narrativas & 20,26 & Descarta a utilização para fins de propaganda \\
\hline Esfera pública & 21 & Abertura à opinião pública \\
\hline
\end{tabular}

Tabela 3: Tópicos do "Manifesto public sculpture in the context of american democracy"

Fonte: Armajani, 1995

\section{NOTA BIOGRÁFICA}

Professor Auxiliar Convidado, doutoramento em Estudos do Património, doutoramento em Conservação e Restauro de Bens Culturais, mestrado em Conservação e Restauro de Bens Culturais. Investigador permanente do Centro de Investigação em Ciência e Tecnologia das Artes, coordenador do R3iAP.

ORCID: https://orcid.org/oooo-0003-4022-7771

Email: jgabreu@porto.ucp.pt

Morada: Universidade Católica Portuguesa, Rua de Diogo Botelho, 1327, 4169-005 Porto

Submetido: 02/09/2019

Aceite: $31 / 11 / 2019$ 